\title{
Nurses and midwives demographic shift in Ghana-the policy implications of a looming crisis
}

\author{
James Avoka Asamani ${ }^{1 *}$ (D), Ninon P. Amertil ${ }^{2}$, Hamza Ismaila ${ }^{3}$, Akugri Abande Francis ${ }^{2}$, Margaret M. Chebere $^{3}$ and \\ Juliet Nabyonga-Orem ${ }^{1}$
}

\begin{abstract}
As part of measures to address severe shortage of nurses and midwives, Ghana embarked on massive scale-up of the production of nurses and midwives which has yielded remarkable improvements in nurse staffing levels. It has, however, also resulted in a dramatic demographic shift in the nursing and midwifery workforce in which 71 to $93 \%$ of nurses and midwives by 2018 were 35 years or younger, as compared with 2.8 to $44 \%$ in 2008 . In this commentary, we examine how the drastic generational transition could adversely impact on the quality of nursing care and how the educational advancement needs of the young generation of the nursing and midwifery workforce are not being met. We propose the institution of a national nursing and midwifery mentorship programme and a review of the study leave policy to make it flexible and be based on a comprehensive training needs assessment of the nursing and midwifery workforce. We further advocate that policymakers should also consider upgrading all professional nursing and midwifery programmes to bachelor degrees as this would not only potentially enhance the quality of training but also address the phenomenon of large numbers of nurses and midwives seeking bachelor degree training soon after employment-sometimes putting them at the offending side of organisational policy.
\end{abstract}

Keywords: Human resources for health, Nursing and midwifery workforce, Nursing demographics, Health workforce policy

\section{Introduction}

The global community is increasingly recognising the contribution of nurses and midwives to health service delivery and the need to harness the nursing and midwifery potential towards the attainment of Universal Health Coverage (UHC) and the Sustainable Development Goals (SDGs) especially goal 3. In leaving no one behind as enshrined in the UHC effort, nurses and midwives who undoubtedly have been the bedrock of most healthcare systems and form the bulk of the health workforce $[1,2]$ would have to be a greater part of the efforts.

The 2006 World Health Report classified Ghana among 36 countries in sub-Saharan Africa facing Human Resources for Health (HRH) crisis [3] which became a

\footnotetext{
* Correspondence: jamesavoka@gmail.com

${ }^{1}$ World Health Organization, Regional Office for Africa, Inter-Country Support

Team for Eastern and Southern Africa, Harare, Zimbabwe

Full list of author information is available at the end of the article
}

clarion call for concerted efforts to address a myriad of health workforce challenges notably, inadequate production, excessive out-migration and low wages among others. Consequently, the Ministry of Health developed the HRH strategy, 2007-2011 [4, 5] which outlined a number of strategic interventions including the expansion and liberalisation of the training of health workers, the reintroduction of auxiliary nursing programmes, the establishment of postgraduate specialist training colleges (for doctors, pharmacist, nurses and midwives), review of health workers salary structure and the introduction of staff vehicle hire purchase scheme, to name a few. It would appear that these efforts to a large extent yielded some fruits as the density of doctors, nurses and midwives dramatically improved from 1.07 per 1000 population in 2005 to 2.65 per 1000 population in 2017 [6]. These efforts have not only resulted in improved service coverage towards UHC, but also the country is being

(c) The Author(s). 2019 Open Access This article is distributed under the terms of the Creative Commons Attribution 4.0 International License (http://creativecommons.org/licenses/by/4.0/), which permits unrestricted use, distribution, and reproduction in any medium, provided you give appropriate credit to the original author(s) and the source, provide a link to the Creative Commons license, and indicate if changes were made. The Creative Commons Public Domain Dedication waiver (http://creativecommons.org/publicdomain/zero/1.0/) applies to the data made available in this article, unless otherwise stated. 
cited as a leading producer of physicians, nurses and midwives in sub-Saharan Africa [7, 8].

Out of about 115650 health workers employed in the public sector in 2018, 58\% were nurses and midwives whose numbers increased by $370 \%$ between 2008 and 2018 [9]. Among the nursing and midwifery workforce, $31 \%$ and $22 \%$ are enrolled nurses and community health nurses respectively (who are trained for 2 years). Nevertheless, empirically, there exist lingering workforce shortages and inequitable distribution [10,11] alongside a publicly acknowledged challenge of trained but unemployed nurses and midwives [12, 13]. Although the aforesaid issues continue to preoccupy the health sector policymakers, an examination of the nursing and midwifery demographic transition over the last decade shows a massive youth bulge which must be taken into account in the health workforce policy discourse. Based on the annual operational report of the Ghana Health Service (GHS), we examine the changing age dynamics of the nursing and midwifery workforce in Ghana and advocate for a policy response in terms of mentorship and in-service education management.

\section{Demographic shift among nurses and midwives-2008 and 2018 compared}

Since the last decade, there has been a far-reaching shift in the age profile of the nursing and midwifery workforce in Ghana which appears to have been unaccounted for in the health workforce policy discourse. For example, in 2008, less than 3\% of midwives were younger than 35 years with at least $88 \%$ being older than 46 years, most of whom were set to exit the active workforce (Fig. 1). This certainly rang the alarm bell [14] resulting in the introduction of direct Midwifery Program for Secondary School leavers which was hitherto restricted to only serving nurses. In contrast to the 2008 situation, about $71 \%$ of midwives in 2018 were between 25 and 35 years. Only $12 \%$ of the midwives were older than 46 years compared with $88 \%$ in 2008 . This implies that during the last decade, there were literally too many experienced midwives with fewer younger ones to mentor, a situation which the opposite is currently prevailing whereby the bulk of the current generation of midwives are relatively inexperienced while there are too few clinical mentors to guide them.

Similarly, in 2008, there were two distinct generational cohorts of professional nurses; $43 \%$ of whom were young (25-35 years) and were being mentored by $36 \%$ who were aged 45 years or older. Compared to the situation in $2018,81 \%$ of professional nurses are younger than 35 years who are expected to be mentored by only $7 \%$ experienced ones who are 46 years or older (Fig. 1).

Also, the pattern of the demographic shift in the ages of the auxiliary nursing categories has been like that of the midwives. By 2018, enrolled nurses and community health nurses who were older than 45 years were almost

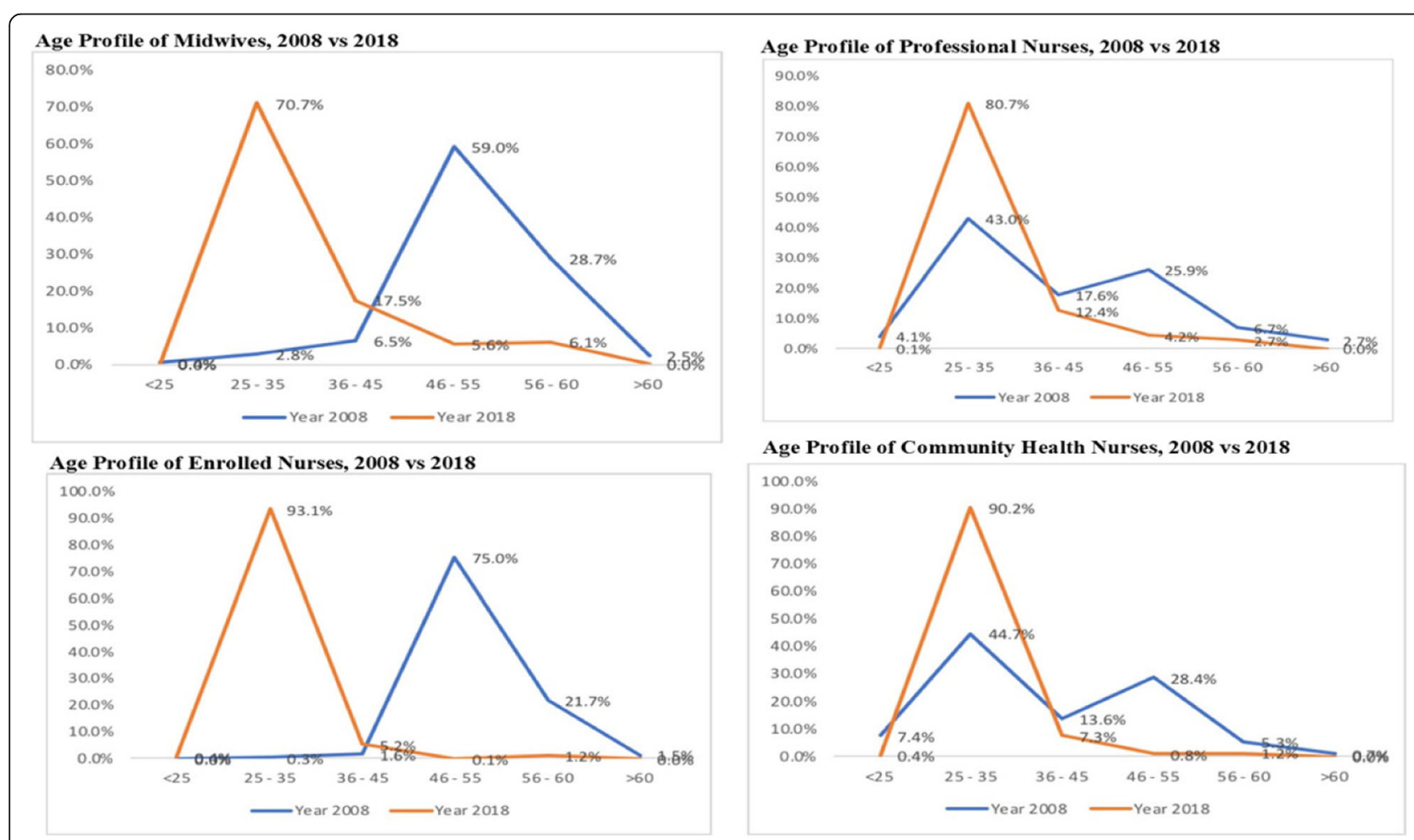

Fig. 1 Age profile of nurses and midwives in the public sector of Ghana, 2008 vs 2018 
extinct in the public health sector (less than 3\% in both cases), as $93 \%$ and $90 \%$ of enrolled and community health nurses respectively were younger than 35 years. Indeed, the median range of working experience of these categories of nurses is also $3-5$ years.

\section{Policy implications}

The foregoing demographic shift in terms of the age profile of nurses and midwives brings to fore several policy implications, some of which we discuss with the view of advocating for operational policy reforms at the $\mathrm{MOH}$ and its agencies.

\section{Institute nursing and midwifery mentorship programme to improve quality of care}

Whilst some have lauded the improvement in the stock of nursing and midwifery workforce, there are also concerns about the quality of nurses and midwives being produced and the impact of same on quality of care $[15,16]$. Undoubtedly, a situation where the care of patients is shifted from quite experienced to relatively inexperienced hands should adversely affect the technical quality of patient care, especially when there are no structured clinical mentorship programmes for midwives and nurses in Ghana beyond the required internships which are seldom monitored and virtually no one gets deferred. In the case of midwives, cultural issues may hinder older mothers from delivering in health facilities because they feel the young midwives are of the age of their children. Under the circumstance, it would be imperative for the $\mathrm{MOH}$ and its agencies to institute a mentorship scheme for nurses and midwives and if necessary, re-engage retired but fitto-practice nurses and midwives to mentor young nurses and midwives.

Also, it has been documented that professional nurses of junior ranks (such as staff nurse and senior staff nurse-those with 1-3 years of working experience) have in many instances been made nurse managers in-charge of service delivery units/wards without adequate preparations [17-19] - roles which are significantly supervisory, clinical leadership and mentorship in nature. This ill-preparedness of the nurse managers could have an adverse consequence on both staff and patient outcomes [20-24]. Beyond concerns of the technical quality of patient care associated with limited clinical experience of the young generation of nurses and midwives, another source of concern is the potential for them to get stressed and burnout due to high workload levels in the roles that are relatively above their level of experience and capacity, a situation which could culminate in increased turnover and ultimately higher vacancy rates. Therefore, the Ministry of Health and its agencies need to explicitly define the criteria to be met, preferably competitive and managerial in nature, for appointment as nurse/midwife manager.

\section{Review in-service training and education policy}

It has been observed that, in recent years, large numbers of young health workers especially nurses and midwives are pursuing further training and education because most of them are initially trained at level of a 2-year certificate or a three-year diploma who are seeking for opportunities to obtain bachelor degrees-a testament that many nurses and midwives are unsatisfied with their non-bachelors level of training. Indeed, evidence from the international literature suggests that patients are much more safer under the care of nurses and midwives who are highly trained at least at the level of bachelors $[25,26]$. Under the prevailing dispensation of study leave policy, the official opportunities given to nurses and midwives to embark on further studies for bachelor degrees appears to be too restrictive which some nurses and midwives even wonder if it will ever get to their turn if they continue to wait in the queue for study leave. Consequently, some nurses and midwives have resorted to flexible modes of education such as weekends, evening and sandwich studies (with or without approval from their employer) which sometimes put them at the offending side of organisational policies.

It is imperative that Ministry of Health and its agencies view the aforesaid as a clarion call to review the policies on study leave which is neither efficient nor meeting the professional needs of the current generation of nurses and midwives. For instance, in 2018, 67\% of GHS' staff education programme focused on full-time studies with only $32 \%$ focusing on weekend, evening and sandwich modes of education combined [9]. The study leave policies should be reviewed to allow flexibility to accommodate the needs of the young generation of nursing and midwifery workforce to eschew resentment and demotivation which is adversely affecting staff performance and service delivery. We advocate for periodic comprehensive training needs assessment of all staff to facilitate the development of a master training plan based on which annual study leave plans can be developed using a bottom-up approach. This should be accompanied with greater emphasis on flexible modes of education (such as weekends, sandwich and evening studies) which tend to be cost-effective from the employer's perspective as these flexible modes of education would allow the employees to continue to provide services whilst pursuing further studies. Finally, it might be worth considering upgrading all professional nursing and midwifery programmes to the level of first degree (baccalaureate programmes) as is the case in some countries in bid to improve the quality of training and also 
mitigate against the mass agitations by nurses and midwives for study leave to undertake degree programmes in nursing and midwifery soon after their employment.

\section{Conclusion}

Escalation of the production of nurses and midwives in Ghana over the last decade has resulted in a drastic shift in the age structure of nurses and midwives. This demographic shift appears to have been without appropriate mechanisms for mentorship which could adversely affect the quality of health care. The nursing and midwifery youth bulge has increased pressure on the administration of the study leave policy of the Ghana health sector. We reckon that these have necessitated the institutionalisation of a nursing and midwifery mentorship programme and a review of the study leave policy as well as to consider upgrading all professional nursing and midwifery programmes to first degrees soon after their employment.

\section{Abbreviations}

HRH: Human Resource for Health; HWF: Health Workforce; MOH: Ministry of Health; SDGs: Sustainable Development Goals; UHC: Universal Health Coverage; WHO: World Health Organization

\section{Acknowledgements}

We are profoundly grateful to Mr. Francis Victor Ekey for assisting us to retrieve historical age profile of Ghanaian public sector nurses.

\section{Funding}

No funding was received for this work

\section{Availability of data and materials}

The datasets supporting our conclusions will be provided upon request.

\section{Authors' contributions}

JAA conceived and designed the analysis; JAA and HI carried out the data collection and analysis and drafted the manuscript. NPA, AAF, MMC and JN contributed to the writing of the manuscript. All authors read, edited and approved the manuscript.

\section{Ethics approval and consent to participate}

The work is based on publicly available data and did not involve the use of human subjects or animals. No ethical approval was required but permission was sought from the Ghana Health Service.

\section{Consent for publication}

All authors have approved the manuscript for submission.

\section{Competing interests}

The authors declare that they have no competing interests.

\section{Publisher's Note}

Springer Nature remains neutral with regard to jurisdictional claims in published maps and institutional affiliations.

\section{Author details}

'World Health Organization, Regional Office for Africa, Inter-Country Support Team for Eastern and Southern Africa, Harare, Zimbabwe. ${ }^{2}$ School of Nursing and Midwifery, Valley View University, Oyibi, Accra, Ghana. ${ }^{3}$ Human Resources Division, Ghana Health Services, Accra, Ghana.
Received: 26 April 2019 Accepted: 12 May 2019

Published online: 22 May 2019

\section{References}

1. Boniol M, Mclsaac M, Xu L, Wuliji T, Diallo K, Campbell J. Gender equity in the health workforce: analysis of 104 countries. Geneva: World Health Organ; 2019. p. 8.

2. George A. Human resources for health: a gender analysis. 2007. p. 57. https://www.who.int/social_determinants/resources/human_resources_for_ health_wgkn_2007.pdf?ua=1

3. WHO. The world health report: 2006: working together for health. 2006; Available from: http://apps.who.int/iris/handle/10665/43432. [Cited 10 Oct 2016]

4. $\mathrm{MOH}$. Human resource policies and strategies for the health sector, 2007-2011 [Internet]. Ghana: Ministry of Health; 2007. Available from: www.moh.gov.gh

5. Sagoe K. Human resources for health - challenges and strategies to address them in sub-Saharan Africa. 2013. Available from: http://www.fatoafrique. org/congres2013/IMG/pdf/sagoe_kenneth_ppt_fr.pdf. [cited 24 Mar 2019]

6. GHS. Human resource directorate annual report for 2017. Accra: Ghana Health Service, Human Resource Directorate; 2018.

7. Campbell J, Buchan J, Cometto G, David B, Dussault G, Fogstad H, et al. Human resources for health and universal health coverage: fostering equity and effective coverage. Bull World Health Org. 2013;91(11):853-63 Available from: http://www.scielosp.org/scielo.php?pid=\$0042 $96862013001100853 \&$ script=sci_arttext. [cited 29 Jan 2017].

8. WHO. Equitable access to functional health workforce and community health workers in the africa region [Internet], WHO Regional Forum on Strengthening Health Systems for the SDGs and UHC. Windhoek; 2016.

9. GHS. Human resource annual report - 2018. Accra: Ghana Health Service; 2019.

10. Asamani JA, Chebere MM, Barton PM, D'Almeida SA, Odame EA, Oppong R. Forecast of healthcare facilities and health workforce requirements for the public sector in Ghana, 2016-2026. Int J Health Policy Manag. 2018;0(0) Available from: http://www.ijhpm.com/article_3525.html. [Cited 7 Aug 2018].

11. Scheffler RM, Mahoney CB, Fulton BD, Dal Poz MR, Preker AS. Estimates of health care professional shortages in sub-Saharan Africa by 2015. Health Aff (Millwood). 2009;28(5):w849-62 Available from: http://content.healthaffairs. org/cgi/doi/10.1377/hlthaff.28.5.w849. [Cited 3 Jun 2016].

12. Amadu $\mathrm{H}$. The rising trend in nurses unemployment: the need to include entrepreneurship in our nursing colleges curriculum [Internet]: Modern Ghana; 2018. Available from: https://www.modernghana.com/news/886516/ the-rising-trend-in-nurses-unemployment-the-need-to-include.html. [cited 24 Mar 2019]

13. Elorm. Bonded nurses and midwives demand postings to health facilities [Internet]: Ghana Business News; 2018. Available from: https://www. ghanabusinessnews.com/2018/09/07/bonded-nurses-and-midwivesdemand-postings-to-health-facilities/. [Cited 24 Mar 2019]

14. Appiah-Denkyira E, Herbst $\mathrm{CH}$. Toward evidence-based interventions for HRH. 2013 . Available from: http://elibrary.worldbank.org/doi/abs/10.1596/ 9780821396674_CH01. [Cited 29 Jan 2017].

15. Dzomeku MV. Maternal satisfaction with care during labour: a case study of the Mampong-Ashanti district hospital maternity unit in Ghana. Int J Nurs Midwifery. 2011;3(3):30-4 Available from: http://www.academicjournals.org/ journal/IJNM/article-full-text-pdf/154DAFD809. [cited 17 Nov 2016].

16. Moyer CA, Rominski S, Nakua EK, Dzomeku VM, Agyei-Baffour P, Lori JR. Exposure to disrespectful patient care during training: data from midwifery students at 15 midwifery schools in Ghana. Midwifery. 2016;41:39-44 Available from: http://www.sciencedirect.com/science/article/pii/ S026661381630119X. [Cited 18 Dec 2016].

17. Asamani JA, Kwafo EO, Ansah-Ofei AM. Planning among nurse managers in district hospitals in Ghana. Nurs Manag (Harrow). 2013;20(8):26-31 Available from: http://journals.rcni.com/doi/full/10.7748/nm2013.12.20.8.26.e1151. [Cited 18 Apr 2016].

18. Ofei AM, Sakyi EK, Buabeng T, Mwini-Nyaledzigbor P, Atindanbila S. Perceived and preferred leadership behavior of nurse managers at the unit level in the Greater Accra Region: a mixed method approach. Int Rev Soc Sci. 2014;2(2):42-61.

19. Peter Adatara JA. Challenges of being a hospital nurse manager in the Volta region of Ghana: a qualitative study. Nusing Manag Harrows. 2019:25(5):35-42 Available from: https://journals.rcni.com/nursingmanagement/evidence-and-practice/challenges-of-being-a-hospital-nurse- 
manager-in-the-volta-region-of-ghana-a-qualitative-study-nm.2018.e1773/ print/abs. [Cited 24 Mar 2019].

20. Azaare J, Gross J. The nature of leadership style in nursing management. $\mathrm{Br}$ J Nurs. 2011;20(11):672-80 Available from: https://www.magonlinelibrary. com/doi/abs/10.12968/bjon.2011.20.11.672. [Cited 27 Sep 2013].

21. Asamani JA, Naab F, Ofei AMA. Leadership styles in nursing management: implications for staff outcomes. J Health Sci. 2016;6(1):1-14 Available from: https://www.jhsci.ba/ojs/index.php/jhsci/article/view/533. [Cited 18 Apr 2016]

22. Cummings GG, MacGregor T, Davey M, Lee H, Wong CA, Lo E, et al. Leadership styles and outcome patterns for the nursing workforce and work environment: a systematic review. Int J Nurs Stud. 2010;47(3):363-85 Available from: http://www.sciencedirect.com/science/article/pii/ S0020748909002831. [Cited 27 Sep 2013].

23. Cummings GG, Midodzi WK, Wong CA, Estabrooks CA. The contribution of hospital nursing leadership styles to 30-day patient mortality. Nurs Res [Internet]. 2010;59(5):331-9 Available from: https://www.ncbi.nlm.nih.gov/ pubmed/20686431. [Cited 25 May 2016].

24. Wong CA, Cummings GG. The relationship between nursing leadership and patient outcomes: a systematic review. J Nurs Manag. 2007;15(5):508-21 Available from: http://onlinelibrary.wiley.com/doi/10.1111/j.1365-2834.2007. 00723.x/full. [Cited 27 Sep 2013].

25. Kane RL, Shamliyan TA, Mueller C, Duval S, Wilt TJ. The association of registered nurse staffing levels and patient outcomes: systematic review and meta-analysis. Med Care. 2007;45(12):1195 Available from: https:// journals.Iww.com/Iww-medicalcare/Abstract/2007/12000/The_Association_ of Registered_Nurse_Staffing.11.aspx. [Cited 6 May 2019].

26. Aiken LH, Sloane DM, Bruyneel L, den HKV, Griffiths P, Busse R, et al. Nurse staffing and education and hospital mortality in nine European countries: a retrospective observational study. Lancet. 2014;383(9931):1824-30 Available from: https://www.thelancet.com/journals/lancet/article/PIIS01406736(13)62631-8/abstract. [Cited 6 May 2019].

Ready to submit your research? Choose BMC and benefit from:

- fast, convenient online submission

- thorough peer review by experienced researchers in your field

- rapid publication on acceptance

- support for research data, including large and complex data types

- gold Open Access which fosters wider collaboration and increased citations

- maximum visibility for your research: over $100 \mathrm{M}$ website views per year

At $\mathrm{BMC}$, research is always in progress.

Learn more biomedcentral.com/submissions 